\title{
A Comparative Analysis of Editorials of 'The Nation' and 'the News' the Case Study Of Pak-U.S Relation Issues Duration: Sep 2001 to Sep 2003
}

\author{
Dr. Abdul Wajid Khan ${ }^{1}$, Dr. Arshad Ali ${ }^{2}$, Malik Adnan ${ }^{3}$, Shehla Jabeen ${ }^{4}$ \\ ${ }^{1}$ Assistant Professor, Department of Media Studies, The Islamia University of Bahawalpur, Pakistan, \\ ${ }^{2}$ Assistant Professor, Center for Media and Communication Studies, University of Gujrat, Pakistan, \\ ${ }^{3}$ Lecturer (Communication Studies), Directorate of Distance Education, Bahauddin Zakariya University Multan, \\ Pakistan, \\ ${ }^{4}$ Lecturer (Mass Communication), Lahore College for Women University Lahore, Pakistan,
}

\begin{abstract}
The study aims at investigating as how Pak-US relations issues is being represented andportrayed in two leading Pakistan's National newspapers. Two elite newspapers The Nation and The News have been selected for research. This study analyzed the editorials of both newspapers published from September 2001 to September 2003as the universe of the study. Theoretical inspiration is drawn from the postulates of Herman and Chomsky's Propaganda Model and framing theory. This research study has employed a combination of the quantitative and qualitative techniques of content analysis to analyze the contents.
\end{abstract}

Key words: Pakistan, USA, Relations, Kashmir issue, Negotiation and Terrorism

\section{Introduction}

After 9 September attacks the nature of Pakistan-U.S relations took anextreme turn. The policy of U.S, with respect to Pakistan was changed with new proportions. The U.S president George W. Bush clearlystunned by the intensity of the attacks vowed to take harsh action against the perpetrators of the terrorism in United States. He pledged to remove terrorism form its roots and appealed to the whole world to come forward and join the America in decrease the danger of terrorism. Pakistan again became a most joinedsupporter of USA in conflict against terrorism, but the skeptics in armed establishment and in commoncommunityof Pakistan still had doubts about trustworthiness of relationship with America. The reality is that USA is a reliable and credible partner of Pakistan, till the time that no strong lobby is activated against Pakistan in U.S and concern of India and Pakistan is convergent in this area while getting united on particular issue to address, the moment, interest of India and Pakistan is diverged, the lobby starts acting against Pakistan in United States.

After an overview of different epoch of U.S-Pak relations, Pakistan wants and formulate its policy because U.S. in a more practical manner. Pakistan policy - makers should keep in mind that only a democratic government can forge sustainable and long term relations with America. Theexaminer intends to study the editorial treatment of Pak-America relation issues in the Nation and The News by applying the following theoretical perspectives. Propaganda Model, Theory of Framing. On 11 September 2001, the world politics changed, as Afghanistan visited the world in a cruel, dreadful way. On October 7, 2001 United Statesstarted the conflict on Afghanistan. The main goal was to handle Osama Bin Laden and his Al-Qaeda officials. A secure, self-governing, successful Pakistan is considered essential to United States interests. America concerns about Pakistan compriselocal and worldwideviolence.

The researcher in the proposed research intends to Pak-U.S. relations post $9 / 11$ as it changed the international situation researcher'stry to give a systematic analysis of the editorial dealing in two leading English newspapers (The News, The Nation) during the time period of September 2001 to September 2003.

\section{Why English Press}

In Pakistan press is considered more reliable than electronic media. English is an international language and in Pakistan mostly well qualified people and policy makers read an English newspaper that's why it is also called elite newspapers. It is considered that English press is comparatively more responsible. The Nation, The News are two foremost English dailies of Pakistan and having huge circulation and popularity among the readers and these newspapers by and large, remains serious and responsible on the issues of national and international importance. Moreover, the official website of Pakistan Government grades the selected newspapers as the top three newspapers of Pakistan. 


\section{The News}

Jang Group of publications launched an English newspaper with the name "The News" of February 11, 1991, from Karachi, Lahore, Rawalpindi and London at the same time. "The News" is said be neutral and unbiased and is believed to present both sides of the picture. The News is following the policy of "no policy". Sometimes it seems as pro leftist or moderate are given more importance by this newspaper. However, this newspaper never opposes the government and tries to give a balance views while covering sensitive issues.

\section{The Nation}

Nawaiwaqt group started the newspaper on October 1, 1986 from Lahore, Chief Editor and editor of The Nation are MajeedNizami andSherinMazarirespectively.The Nation like his sister paper Nawaiwaqt is more like an ideological newspaper. Though it is much liberal than Nawaiwaqt, yet it is most conservative among the other English newspapers. This newspaper is mostly supportive of Muslim League, it strongly believes in the ideology of Pakistan, therefore, caters readership of the right and criticism against the west can be traced form editorial policy of The Nation.

\section{Research design} hypothesis.

The researcher worked research design of content analysis to include the research questions and

\section{Period of Study}

Editorials of daily The Nation and Daily the News have been selected for the period of two years from September 2001 to September 2003.

\section{Census Study}

The researcher not applied any sampling technique for the purpose of analysis of editorials because all editorials related to this particular topic published form September 2001 to September 2003 are analyzed and investigated. So, it was a census study.

\section{Sample Frame}

The editorials of both the paper on the issues of US invasion of Afghanistan, handling over of Osama Bin Laden to US, Dialogue with Taliban, Freedom to Kashmir with support of U.S and Pak-US relation during 9-11-2001 to 9-11-2003 are selected as the sample of study.

\section{Sample Size} the study.

The editorials of both the papers on the issues under debate of Pak-US relations are the sample size of

\section{Research Questions}

The research questions would observe that in what way the Pakistani print media "The News" and "The Nation" frame the issues in Pak-US relations. The study covers the following research questions.

1. How much coverage was given on the issues under study of Pak-US relations by "The Nation" from 9-11-2001 to 9-11-2003?

2. How much coverage was given on the issues under study of Pak-US relations by "The News" from 9-11-2001 to 9-11-2003?

3. How was the Pak- US relation issues treated by "The Nation".

4. How was the Pak- US relation issues treated by "The News".

5. What were the similarities and differences among 'The Nation' and 'The News' in the editorial

Hypothesis 1 coverage on the subject under study?.

\section{Rationale 1}

The News support Pakistan's foreign policy on Pak-US relation issues.

The News has supportive attitude towards Government's policy on Pak-US relation issues due to its progressive approach.

\section{Hypothesis 2}

Rationale 2

The Nation opposes Pakistan's Government policy on Pak-US relation issues.

The Nation seems to be conservative towards its set principles regarding Pak-US relation issues. 


\section{Data Presentation}

Quantitative data is present in the shape of tables and graphs, whereas qualitative data is in the form of explanations of the results of the study.

\section{Findings and Analysis}

Coverage of 'The Nation' and 'The News' on the issues of Freedom to Kashmir with the support of United States (A), US invasion of Afghanistan (B), Handing Over of Osama Bin Laden to the Americans (C) and Initiation of Dialogue with Taliban (D).

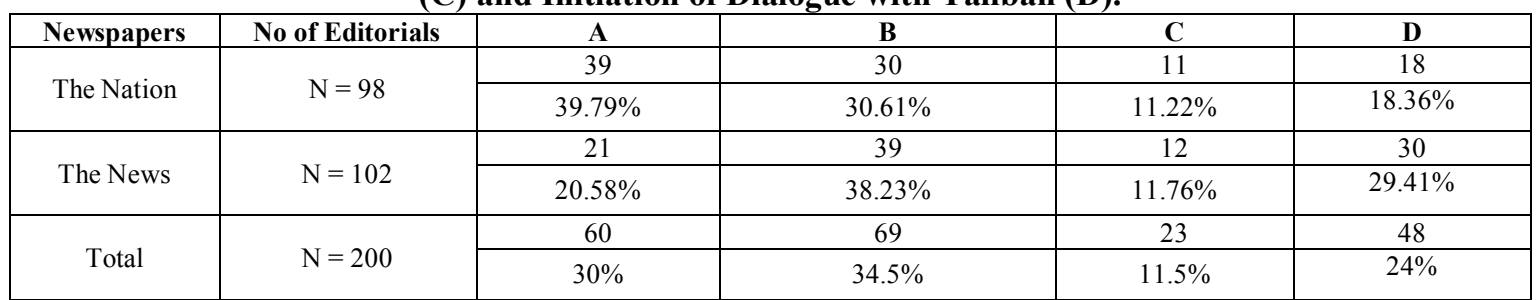

$\mathrm{N}=$ Number of Editorials

$\mathrm{A}=$ Freedom to Kashmir with the support of US

$\mathrm{B}=\mathrm{US}$ invasion of Afghanistan

$\mathrm{C}=$ Handling over of Osama Bin Laden to the Americans

$\mathrm{D}=$ Initiation of Dialogue with Taliban

This table indicates that total coverage of editorials of The Nation and The News on the issues A, B, C,D. A total number of 200 editorials in print by both the papers. Out of them 60 editorials (30\%) published on issue (A) freedom to Kashmir with the support of US, 69 editorials (34.5\%) on issue (B) US invasion of Afghanistan, 23 editorials (11.5\%) on issue (C) handling over of Osama Bin Laden to Americans, and 48 editorials (24) appeared on the issue (D) initiation of dialogue with Taliban. The News gave $20.58 \%$ coverage to the issue A, 38.23\% to the issue D, on the other hand the Nation covered $39.79 \%$ the issue (A) $30.61 \%$ issue (B), 11.225 issue (C) and $18.36 \%$ on issue (D). So, The Nation gave more coverage on issue A while The News more discussed to the issue $\mathrm{B}$.

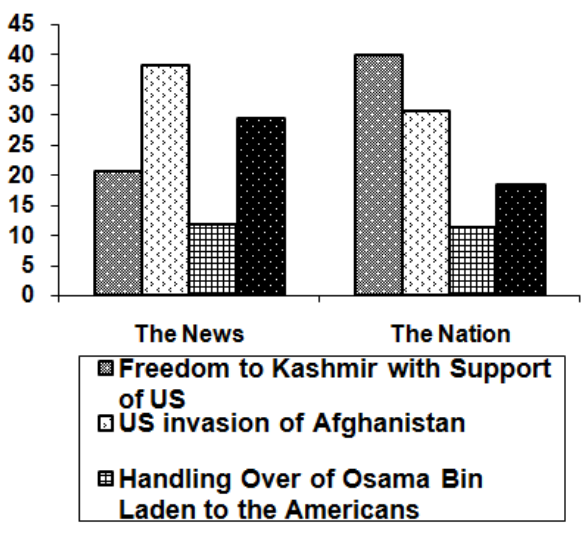

Freedom to Kashmir with support of United State (A)

\begin{tabular}{|l|c|c|c|c|}
\hline \multicolumn{1}{|c|}{ Newspaper } & $\begin{array}{c}\text { Number of } \\
\text { Editorial }\end{array}$ & + & - & $\mathbf{0}$ \\
\hline The Nation & $\mathrm{N}=39$ & 20 & 14 & 5 \\
& $\mathrm{~N}=21$ & $91.28 \%$ & $35.89 \%$ & $12.82 \%$ \\
\hline The News & $92.85 \%$ & $42.85 \%$ & 3 \\
& & $14.28 \%$ \\
\hline
\end{tabular}

The issue of providing of kashmiris freedom with the support of the US is favoued by 20 out of 39 editorials of the Nation and 9 out of 21 editorials of the News. This table reflects mostly contents off The News and The Nation on issue $\mathrm{A}$ is in favour of Pak government stance. 


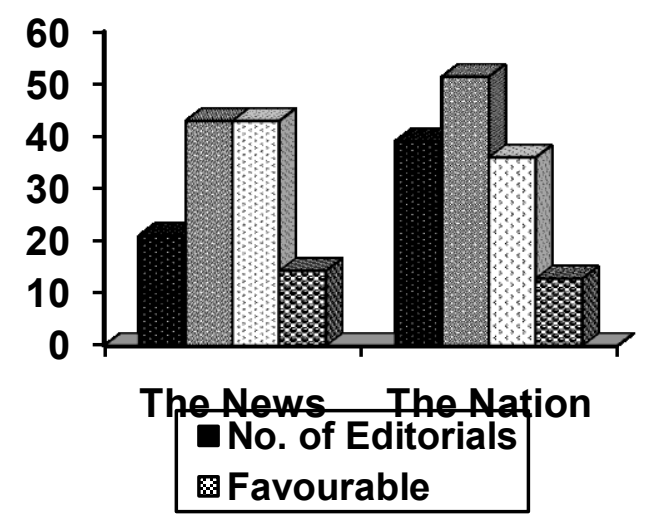

US invasion of Afghanistan (B)

\begin{tabular}{|l|c|c|c|c|}
\hline \multicolumn{1}{|c|}{ Newspaper } & $\begin{array}{c}\text { Number of } \\
\text { Editorial }\end{array}$ & + & - & $\mathbf{0}$ \\
\hline The Nation & $\mathrm{N}=30$ & $\begin{array}{c}5 \\
16.66 \%\end{array}$ & $\begin{array}{c}21 \\
70 \%\end{array}$ \\
\hline The News & $\mathrm{N}=39$ & 9 & 25 & $43.33 \%$ \\
\hline
\end{tabular}

The US invasion of Afghanistan figured prominently in the editorials under review as the Nation devoted 30 editorials to the issue while 39 editorials focused on the issue under review. It was $16.6 \%$ of editorials of the Nation which favoured the invasion with $70 \%$ against it. However, it was The News which had a lower rate of unfavourable editorials printed on the subject.

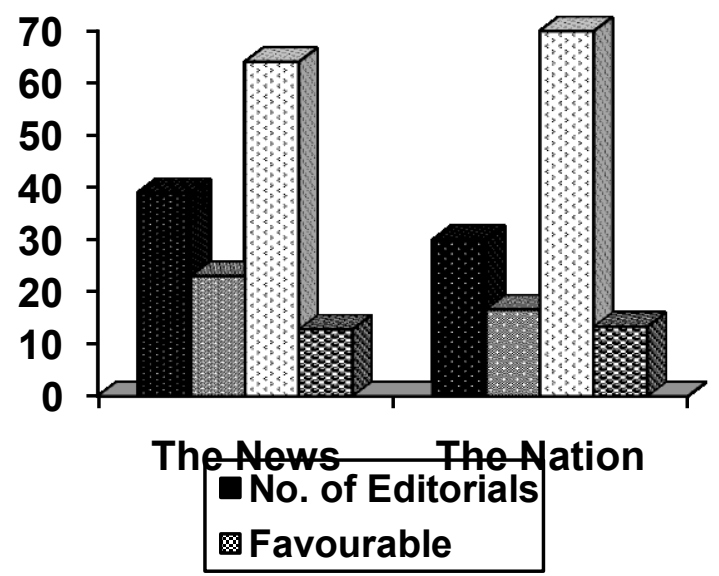

Handling Over of Osama Bin Laden to the Americans (C)

\begin{tabular}{|l|c|c|c|c|}
\hline \multicolumn{1}{|c|}{ Newspaper } & $\begin{array}{c}\text { Number of } \\
\text { Editorial }\end{array}$ & + & - & $\mathbf{0}$ \\
\hline The Nation & $\mathrm{N}=11$ & 5 & 3 & 3 \\
& $\mathrm{~N}=12$ & $45.45 \%$ & $27.27 \%$ & $27.27 \%$ \\
\hline The News & 5 & 7 & 0 \\
& & $41.66 \%$ & $58.33 \%$ & $0 \%$ \\
\hline
\end{tabular}

The issue of Osama Bin Laden to the Americans was a conflicting one and the Nation had $45.45 \%$ of its total 11 editorials in favour of his turning over to US authorities while the News differed with the government stance and had $58.33 \%$ of its 12 editorials against the government policy. 


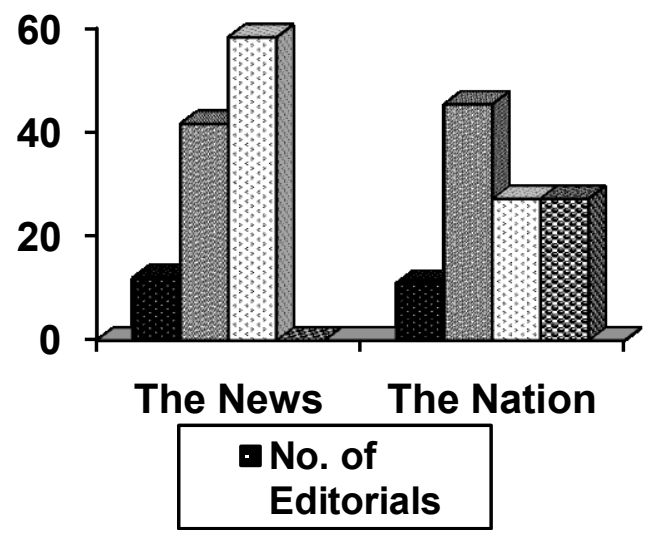

Initiation of Dialogue with Taliban (D)

\begin{tabular}{|l|c|c|c|c|}
\hline \multicolumn{1}{|c|}{ Newspaper } & $\begin{array}{c}\text { Number of } \\
\text { Editorial }\end{array}$ & + & - & $\mathbf{0}$ \\
\hline The Nation & $\mathrm{N}=18$ & 10 & 5 & 3 \\
& $\mathrm{~N}=30$ & $55.55 \%$ & $70 \%$ & $13.33 \%$ \\
\hline The News & $13.33 \%$ & $73.33 \%$ & 4 \\
& $\mathrm{~N}$ & $13.33 \%$ \\
\hline
\end{tabular}

The initiation of dialogue with the Taliban is a tricky question and has 18 editorials which mention this and out of them $55.55 \%$ of the Nation editorials are in favour while the News has 73.33 are against dialogue with the Taliban. This shows a great difference of opinion within the two groups of newspapers and is a point of concern still with the American invasion being 10 years old.

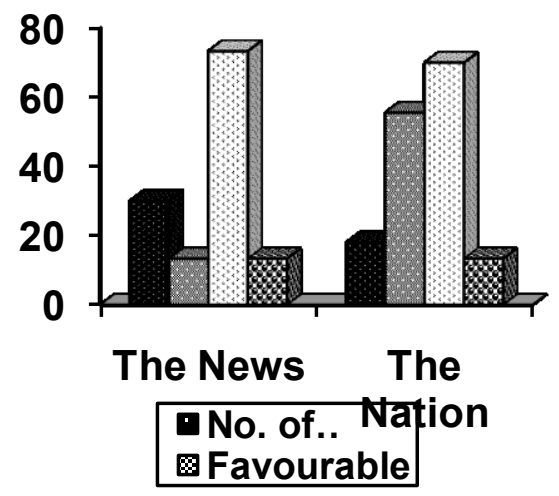

III. Results and Conclusion

The happening of 9/11 and United States war against violence significantly changed the globesituation and overseas policies of the countries. Pakistan, who was the sole ally of Taliban, not only changed her Afghan policy, even North Atlantic Treaty Organization (NATO) launched its first operation outside the Europe and America.

This particular study has been conducted to analyze the Pak-UAmerica relation issues. For this purpose, two newspapers, The News and The Nation have been selected for research. In this regard editorials of both newspapers form September 2001 to September 2003 have been considered for analysis and answers of the research questions were tried to find out.

1. How much converge was given on the issues under study of Pak-U.S relations by "The Nation" from 9-11-2001 to 9-11-2003.

98 editorials were found published in The Nation during the period of study. The Nation published $39.79 \%$ editorials on issue (A), $30.61 \%$ on issue (B), $11.22 \%$ on issue (C) and $18.36 \%$ on issue (D).

2. How much converge was given on the issues under study of Pak-U.S relations by "The News" from 911-2001 to 9-11-2003.

102 editorials were found published in The News during the period of study. The News published $20.58 \%$ editorials on issue (A), $38.23 \%$ on issue (B), $17.76 \%$ on issue (C) and $29.41 \%$ on issue (D).

3. How was Pak-U.S relation issues treated by "The Nation" 
The Nation gave the importance of the issues on A, B, C and D as The Nation published $39.79 \%$ editorial on the issue (A). Its $51.28 \%$ contents were positive, $35.89 \%$ editorials were negative, and $12.82 \%$ editorials were in neutral tone. The Nation covered the issue B, in $30.61 \%$ editorials. Its $16.66 \%$ editorials were positive, $70 \%$ were negative and $13.33 \%$ editorials were neutral. The Nation covered the issue $\mathrm{C}$ in $11.22 \%$ editorials. Its $45.45 \%$ editorials were positive, $27.27 \%$ editorials were negative and $27.27 \%$ editorials were in unbiased way. The Nation covered the issue D in $11.36 \%$ editorials. Its $55.55 \%$ editorials were positive, $70 \%$ editorials were negative and $13.33 \%$ editorials were in neutral tone. So, we may conclude that on the issue A and issue C The Nation was in favour of Pakistan's govt. policy while on the issue B and issue D The Nation opposed Pakistan's government.

\section{How was Pak-U.S relation issues treated by "The News"}

The News gave the importance of the issue A, B, C and D, as The News gave the coverage on the issue A in its $20.58 \%$ editorials its $42.85 \%$ contents were positive, and $42.85 \%$ were negative, $14.28 \%$ in supportive way. The News covered the topic B in its $38.23 \%$ editorials. Its $23.07 \%$ editorials were supportive, $64.10 \%$ editorials were negative and $12.82 \%$ were in neutral tone. The News gave the importance of the issue $\mathrm{C} 11.76 \%$ editorials. It $46.66 \%$ editorials were positive and $58.33 \%$ were negative. The News gave the coverage of issue D in its $29.41 \%$ editorials. Its $13.33 \%$ editorials were supportive and neutral tone, while a large number of $73.33 \%$ editorials consist on opposed contents. So, it seems that on the issue A, The News covered the issue in equal way, positive as well as negative. While The News covered the issues B, C and D in negative tone.

\section{What were the similarities and differences among "The Nation" and "The News" in the editorial coverage on the subject under study?}

On the issue A both newspaper gave the positive comments to the Pak government, while to the some extent gave negative comment to $35 \%$ and $42 \%$. On the issue B, both the paper gave unfavorable comments. On the issue $\mathrm{C}$ and $\mathrm{D}$ The Nation favored the Pak government policy while The News covered the issue in negative way.

The finding of the study reveals that may first hypothesis. "The News support Pakistan foreign policy on Pak-U.S relation issues". The findings revealed that on the issue A, The News favoured the government policies as well as they criticized the government with same ratio. But on the issues B, C and D The News criticized the government policies. So, my first hypothesis is rejected.

The second hypothesis "The Nation opposed Pakistan government policy on Pak-U.S relation issues". My findings exposed that on the issue B and D my hypothesis stands validated while on the issue A and C my hypothesis stands rejected.

How has the world changed after the awful events of 9/11? Internally, Washington is still in grief and conducting and internal argue on its security lapses. However there has been a sea change in its foreign policy.

It continues to put nations and its own immigrants to the stringent Bush test of "either you are with us or against us," compromising the U.S Dream in the process. Two years after initiation its military offensive against horror, the America may just be facing a crueltruth. Mainly that it may have established its armedskills but it has lost the battle for the hearts and minds of the very people whose fate it hopes to influence to tout out the sentiments that led to $9 / 11$.

\section{References}

[1]. Ahmar, M. (2003). Introduction, The World after September 11: Challenges and Opportunities, Karachi: BCC and T.Press

[2]. Burke, S. (1973). Pakistan's Foreign Policy: An Historical Analysis, Karachi: Oxford University Press.

[3]. Comsky, N. (2004). Media Control The Spectacular Achievements of Propaganda. (2 ${ }^{\text {nd }}$ Edition) Lahore: Vanguard Books.

[4]. Curtis, L. (2008). U.S-Pakistan Relations. The Heritage Foundation, 1059. Available at http://www.heritage.org/research/ middleeast/ tst01 2208.cfm.

[5]. Dennis Kux, (1993). The U.S and Pak, National Defense, University Press, Inc. p.124.

[6]. Entman, Robert M. (1993). Framing: Toward Clarification of a Fractured Paradigm, Journal of Communication 43(4), pp.51-58.

[7]. Ferhat Muhammad, (1991). A History of U.S-Pak Relations, Lahore: Vanguard Books, pp.8-44.

[8]. Fischer, M.M.L.C., \& Fischer, M. (2004). Pakistan Under Siege - Pakistan after

[9]. Hussain, R. M. (2003). The Concept of Terrorism: Myth or Reality? In M. Ahmar (Ed.), The World after September 11: Challenges and Opportunities, Karachi: BCC and

[10]. Kelly, C.B. and Beasley, F.V. (2009). Pakistan and U.S. Relations. New York: Nova Science Publishers, Inc. pp.95-103.

[11]. Mughees (1994). Elite Press Editorial Framing of U.S. Foreign Policy: The Case Pakistan and the New York Times, The Washington Post and the Loss Angeles Times (Doctoral Dissertation, University of IOWA, 1994).

[12]. Musharraf, P. (2006). In the Line of Fire: A Memoir Retrieved January 2008 from http://hammadmemon-wordpress.com/2006/10/3.

[13]. Nazar, J. (2003). A History of U.S-Pakistan relations, Retrieved December 2007 from http://www.chowk.com/articles/6843.

[14]. Noshina, S. (2007). U.S. Media Framing of Foreign Countries Image: An Analytical Perspective, Canadian Journal of Media Studied, 2(1), Retrieved August 2007

[15]. Sattar, A. (2007). Pakistan's Foreign Policy (1947-2005) A Concise History, Karachi: Oxford University Press.

[16]. Siraj, A.S. and Ramaprasad, J. (2007). Image of Pakistan in Elite U.S Newspapers: Exploring News Framing, Retrieved May 15, 2009, http://www.issi.org.pk/journal/2007_fils/no_4/article/a1.htm.

[17]. Ziring, L. (1990). Pakistan Foreign Policy: An Historical Analysis, Karachi: Oxford University Press. 